\title{
Impact of Intercropping on Growth and Productivity of Muskdana (Abelmoschus Moschatus Medic.) Under Acacia Mangium Based Multitier Agro Forestry system
}

\author{
Lokesh Chandraker* and RK Prajapati \\ Department of Forestry, Indira Gandhi Agricultural University, India
}

Submission: October 09, 2017; Published: October 20, 2017

*Corresponding author: Lokesh Chandraker, Department of Forestry, Indira Gandhi Agricultural University, India, Tel: 9926251445;

Email: chandraker3@gmail.com

\begin{abstract}
An experiment was conducted to study the impact of intercropping on growth and productivity of Muskdana (Abelmoschus moschatus medic.) under Acacia mangium based multitier Agro forestry system was carried out at Research Farm, Department of Forestry, IGAU, Raipur (C.G.). The design followed was randomized block design with three replications. The observations regarding morphological growth characters viz., plant height, number of leaves and collar diameter. Yield attributes viz., no of capsules plant ${ }^{-1}$, no. of seed capsules ${ }^{-1}$, seed test weight, seed yield plot $^{-1}$, seed yield hectare ${ }^{-1}$ and oil yield hectare ${ }^{-1}$ were tabulated and analyzed statistically using randomized block design. The results revealed that the morphological characters of Muskdana viz., plant height, number of leaves and collar diameter were recorded maximum in vermin compost $100 \%\left(\mathrm{~T}_{2}\right)$ treatment. Farther the highest Number of capsules/plant (22.37 No.), Number of seed/capsules (110.33 No.), Seed test weight (1.78 gram), seed yield (10.04 q/ha) and oil yield (1.16 kg/ha) was recorded in T2 treatment $100 \%$ Vermi compost @ 10 Ton/ha was applied which is superior value among other treatments. However, the minimum average plant height (42.57cm), was observed in T3 $(42.57 \mathrm{~cm}) 100 \%$ Mahua cake the lowest Number of capsules/plant (15.74 No.), Number of seed/capsules ( 99.67 No.) and seed yield ( $8.30 \mathrm{q} / \mathrm{ha})$ was recorded in treatment $\left(\mathrm{T}_{3}\right)$ 100\% Mahua cake this may be some allopathic effect.
\end{abstract}

Keywords: Muskdana; Abelmoschus moschatus; Agro forestry; Intercropping; Vermi compost; FYM; Mahua cake; organic manure and medicinal crop

\section{Introduction}

Agro forestry is an activity that combines production on the same plot of land, from annual agricultural activities (such as crops and pasture) and delayed long-term production by trees (for example timber and services). This is obtained either by planting trees on agricultural land or by cropping (for example after thinning) on forested land. A large number of people in developing countries have traditionally depended on products derived from plants, especially from forest for domestic and commercial uses. About $12.5 \%$ of the 422,000 plant species demarcated worldwide are reported to have medicinal value; but only a few hundred are known to be cultivation with dwindling supplies from natural sources and increasing global demand, the MAPs will need to be cultivated to ensure their regular supply as well as cultivation conservation.

As world population increases, the need for more productive and sustainable use of the land becomes more urgent. According to the United Nations, more than 7 billion people populated the Earth in 2011 and this number is expected to go up to 9.3 billion by the mid-century. To meet the demand for food by 2050 , production will have to increase by over $60 \%$. These figures, coupled with current problems born out of past and existing nonsustainable land use practices, provide the case for changing the way we manage lands and our production of agricultural and tree goods. Thanks to its multifunctional properties, Agro forestry is part of the solution to addressing these issues, whether they are environmental, economic or social.

Silvi-agriculture system is one of the important agroforestry system having agricultural crops, vegetable crops and cultivation of medicinal and aromatic plants. In this system trees providing shade, as it is available in the natural forest. Trees like, Gmelina arborea, Dalbergia sissoo, Acacia mangium, Pongamia pinnata, Jatropha curcas, Tectona grandis and Albizia lebbeck are important component of forest based Silvi-agriculture practices. The practice of different crops of varying heights, rooting pattern 
in the same field at the same time is called multi-tire cropping. Other names of multistoried cropping or multi-layer cropping. Growing plants of different height in the same field at the same time is termed as multistoried cropping. The objective of this system of cropping is to utilize the vertical space more effectively. In this system, the tallest components have foliage of strong light and high evaporative demand and shorter components with foliage requiring shade and or relatively high humidity.

The experiment site multitier plantation of Acacia mangium, Emblica officinalis and Murraya koenigii in research form of IGKV Raipur during 2003. Acacia mangium is in the family Leguminosae, sub-family Mimosoideae. It has rapid early growth, and can attain a height of 30 meters and a diameter of over 60 centimeters [1]. It is an important multipurpose and nitrogen fixing tree species for low lands and one of major fast growing species used in plantation. A. mangium has increasingly important role in efforts to sustainable supply of tree products viz., fuel wood, timber, poles etc., while reducing the pressure on natural ecosystem. It grows well under low productivity land [2]. Aonla (Emblica officinalis) belonging to the family Euphorbiaceae. It is a small or middle sized deciduous, quite fast growing tree. However, in initial 3 to 4 years sufficient space is available which could be advantageously used for raising intercrops.

The curry leaves tree (Murraya koenigii) is a tropical to sub-tropical tree in the family Rutaceae, which is native to India and Sri Lanka. Its leaves are used in many dishes in India, Sri Lanka, and neighboring countries. Curry leaves or 'curry patte' (Hindi) are derived from a handsome, aromatic and more or less deciduous shrub or tree growing wild or planted all over India. The Muskdana (Abelmoschus moschatus Medic.), (Syn. Hibiscus abelmoschus L.), belongs to the family Malvaceae. In Hindi, it is popularly known as muskdana, kasturi bhendi (kasturi = musk; bhendi = lady's finger). In other Indian languages it is known as gukhia korai (Assamese), kasturi bhenda (Telgu), kattukasturi (Malylam), varttilai kasturi (Tamil), lalkasturika (Sanskrit). In India, roots, leaves (rarely), seeds and oil of ambrette are considered valuable traditional medicines. The oil extracted from this crop has a great national and international demand. This increasing demand of ambrette has motivated the farmers to cultivate this important medicinal crop in fairly large areas. With this background in view, the present investigation was undertaken to study the Impact of Intercropping on Growth and Productivity of Muskdana (Abelmoschus Moschatus Medic.) Under Acacia Mangium Based Multitier Agro forestry System.

\section{Materials and Methods}

The experiment was conducted on instructional farm of Department of forestry, IGKV Raipur site is situated in the South-Eastern part of Chhattisgarh. It lies at $21^{\circ} .76^{\prime} \mathrm{N}$ latitude and $81^{\circ} .36^{\prime} \mathrm{E}$ which longitude having an altitude of $295 \mathrm{~m}$. Above mean sea level. The climate of the study area is dry sub-humid tropical with an average rainfall of $1250 \mathrm{~mm}$. Most of the rainfall
(90\%) is received during monsoon season from mid June to mid September. The average number of rainy days varies from 65 to 79. The meteorological data ranges from experiment time in maximum temperature $30.70 \mathrm{C}$ and minimum temp. $24.960 \mathrm{C}$, relative humidity $84.6 \%$, sun shine 7.6 hours and the rainfall $5.6 \mathrm{~mm}$ was recorded in sowing time of seed on July month and the harvesting time temperature and sun shine was increases. Maximum temperature $41.750 \mathrm{C}$ and min. temp. 25.05, relative humidity $39.75 \%$, sun shine 9.3 hours recorded in month of April.

The black clayey soil of experimental field belongs to the order Vertisols and it is locally known as Kanhar. This Kanhar soil are characterized by fine texture, sticky nature, angular blocky structure, low to medium Nitrogen, high Potassium and low to medium Phosphorus with low Organic matter. The soil of experimental area is very rich in organic carbon and other nutrient because of the addition of litter in the soil every year. The experiment was laid out in a randomized block design (RBD) with eight treatments and three replications. Muskdana was sown as intercrop under tree as well as sole crop (without tree). The different combinations of organic manure and fertilizers were applied prior to planting and thoroughly mixed with the soil in a year with single splits under Multitier Acacia mangium based Agro forestry system. Plot size 2.5 x $5 \mathrm{~m}$ were demarcated in such a way that two trees come in each plot laid for 7 different treatments in $8^{\text {th }}$ treatment plots were made in open field without tree. The seed sown on the ridge with spacing $25 \mathrm{~cm}$ plant to plant and $45 \mathrm{~cm}$ row to row in all the plots prepared for the experiment. At the time of ridge and furrow preparation and before sowing of seed in each plot has been treated with the particular treatment according to the designed layout and as per recommended quantity of manure/ fertilizer. Basal dose: $45 \mathrm{~kg} \mathrm{~N}, 37 \mathrm{~kg}$ P2O5 \& $40 \mathrm{~kg} \mathrm{K2O} \mathrm{ha}{ }_{-1}$ in the form of urea, super phosphate and murate of potas, $\mathrm{N}$ is applied in 3 split dozes after 60 days $40 \mathrm{Kg}$ and 120 days $40 \mathrm{Kg}$. Basal dose of fertilizers were mixed in treatment $\mathrm{T}_{7}$ and $\mathrm{T} 8$ plots with shade and without shade respectively. 100\% FYM 20 ton ha-1 was applied in treatment $\mathrm{T}_{1}$, $100 \%$ Vermi compost @10 ton ha- ${ }^{-1}$ was applied in treatment $\mathrm{T}_{2}$. 100\% Mahua cake @ 0.5 ton ha ${ }^{-1}$ in treatment $\mathrm{T}_{3}, 50 \%$ FYM in combination with 50\% Mahua cake in treatment T4, 50\% Vermi compost in combination with $50 \%$ Mahua Cake in treatment $\mathrm{T}_{5}$ and $50 \%$ FYM in combination with 50\% Vermi compost was applied in treatment $\mathrm{T}_{6}$.

Organic manure was applied in plot 1 - 6 as per treatment. However in plot no. 7 and 8 recommended dose of fertilizer were applied. The crops started to flower after 100 to 110 days of after sowing. The female flowers set fruits in nearly three to four days and then the capsules take nearly a month to mature. When the fruits turn brown in color and white opening at angles of the ridges of the pod was harvested. Otherwise they split and seed fall off and go waste. So regular harvesting of capsules from the plots was carried out to pluck the mature capsule kept in the two days for sun drying. After threshing the seed yield was 
recorded for each and every treatment regularly till the maturity of whole crop harvested.

Oil recovery was estimated by hydro distillation method using Clevenger Apparatus [3]. To estimate the oil recovery (\%) 100 gram of crushed seed was taken. The chopped sample was put in $1000 \mathrm{ml}$ capacity flask half filled with water. Distillation was done for about four to five hour. The oil being lighter than water was collected in the burette and reading was recorded. The oil yield per hectare was estimated by extrapolating the oil amount of oil recovered in the distillation. The total oil yield obtained was recorded in kilogram per hectare. The observations regarding morphological growth characters viz., plant height, number of leaves, collar diameter, capsule length, capsules diameter and capsules biomass. Yield attributes viz., no of capsules plant ${ }^{-1}$, no. of seed capsules ${ }^{-1}$, seed test weight, seed yield hectare ${ }^{-1}$ and oil yield hectare ${ }^{-1}$ were tabulated and analyzed statistically using randomized block design. Critical differences (CD) were calculated at $5 \%$ level of significance.

\section{Results and Discussion}

Table 1: Average effect of organic manure and inorganic fertilizer treatments on growth and productivity of Muskdana (Abelmoschus moschatus) intercropped under Acacia mangium based multitier Agro forestry System.

\begin{tabular}{|c|c|c|c|c|c|c|c|c|}
\hline Treatments & $\begin{array}{c}\text { Plant height } \\
\text { (cm) }\end{array}$ & $\begin{array}{c}\text { Collar } \\
\text { diameter } \\
(\mathbf{c m})\end{array}$ & No. of leaves & $\begin{array}{c}\text { Number of } \\
\text { capsules/ } \\
\text { plant }\end{array}$ & $\begin{array}{l}\text { Number } \\
\text { of seed/ } \\
\text { capsules }\end{array}$ & $\begin{array}{c}\text { Seed test } \\
\text { weight (g) }\end{array}$ & $\begin{array}{c}\text { Seed yield } \\
\text { per hectare } \\
\text { (kg) }\end{array}$ & $\begin{array}{l}\text { oil yield per } \\
\text { hectare (kg) }\end{array}$ \\
\hline $\begin{array}{c}\text { T1 FYM } \\
100 \%\end{array}$ & 60.02 & 0.95 & 27.58 & 21.50 & 105.33 & 1.63 & 936.35 & 0.71 \\
\hline T2 VC 100\% & 63.71 & 1.12 & 29.80 & 22.37 & 110.33 & 1.78 & $1,004.85$ & 1.16 \\
\hline T3 MC 100\% & 42.57 & 0.90 & 19.46 & 15.74 & 99.67 & 1.67 & 830.24 & 0.66 \\
\hline $\begin{array}{l}\text { T4 FYM 50\% } \\
\text { + MC 50\% }\end{array}$ & 50.90 & 0.88 & 20.72 & 19.44 & 104.33 & 1.66 & 864.45 & 0.56 \\
\hline $\begin{array}{c}\text { T5 VC } 50 \%+ \\
\text { MC } 50 \%\end{array}$ & 42.85 & 0.79 & 17.62 & 17.13 & 103.33 & 1.66 & 867.84 & 0.57 \\
\hline $\begin{array}{l}\text { T6 FYM 50\% } \\
\text { + VC 50\% }\end{array}$ & 52.49 & 0.99 & 23.78 & 18.53 & 108.67 & 1.69 & 952.37 & 1.01 \\
\hline T7 RDF & 55.21 & 0.95 & 24.27 & 20.12 & 102.33 & 1.58 & 974.69 & 0.78 \\
\hline $\begin{array}{l}\text { T8 without } \\
\text { tree with RDF }\end{array}$ & 56.70 & 0.90 & 22.89 & 18.78 & 100.33 & 1.56 & 893.60 & 0.54 \\
\hline $\operatorname{SEm}( \pm)$ & 4.21 & 0.06 & 2.22 & 1.30 & 1.82 & 0.03 & 25.66 & 0.14 \\
\hline CD (at 5\%) & 12.78 & 0.18 & 6.73 & 3.93 & 5.53 & 0.10 & 77.84 & 0.42 \\
\hline
\end{tabular}

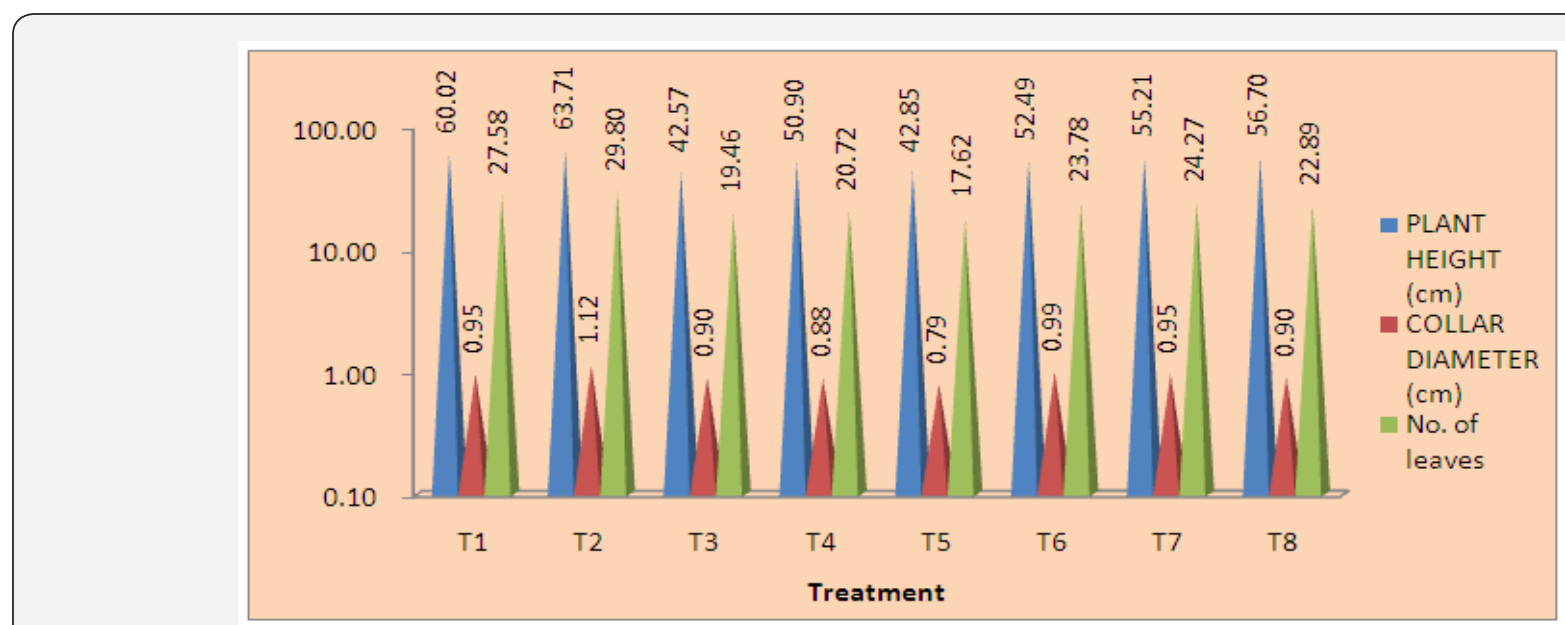

Figure 1: Effect of organic manure and inorganic fertilizer treatments on morphological characters of Muskdana (Abelmoschus moschatus) intercropped under Acacia mangium based multitier Agroforestry System.

The height, collar diameter and number of leaves of Muskdana under different treatments were recorded at 15 days intervals after sowing the crop and their results are presented in table 1 and figure 1 growth character of Muskdana showed statistically significant $(\mathrm{P}<0.05)$ by organic manure and inorganic fertilizer treatments under multitier Agro forestry system and as a sole crop in open condition.

\section{Morphological Characters}

The plant height of Muskdana was significantly influence with the increasing age of crop (Table 1) (Figure 1). The 
Maximum average plant height of Muskdana was recorded in $\mathrm{T}_{2}(63.71 \mathrm{~cm})$ treatment $100 \%$ Vermi compost followed by $\mathrm{T}_{1}$ $(60.02 \mathrm{~cm})$ treatment FYM. The minimum average plant height was observed in $\mathrm{T}_{3}(42.57 \mathrm{~cm}) 100 \%$ Mahua cake treatment in full maturity. This may be low nutrient availability or allelopathic affect of Mahua cake in growth period of crop. The similar results are reported by [4] in Okra (Abelmoschus esculentus) crop and [5] also reported in patchouli crop. The Maximum average collar diameter of Muskdana was recorded in $\mathrm{T}_{2}(1.12 \mathrm{~cm})$ treatments $100 \%$ vermi compost followed by $\mathrm{T}_{6}(0.99 \mathrm{~cm})$ treatment. The minimum collar diameter was observed in $\mathrm{T}_{5}(0.79 \mathrm{~cm})$ VC $50 \%$ + MC 50\% treatment in interaction effects (Table 1) (Figure 1). Similar result was found by [5,6] in patchouli crop. The Maximum average number of leaves of Muskdana was recorded in $\mathrm{T}_{2}$ treatment (29.80) 100\% Vermi compost followed by $\mathrm{T}_{1} \mathrm{FYM}$ treatment (27.58). The minimum number of leaves was observed in $\mathrm{T}_{5}$ (17.62) VC 50\% + MC 50\% treatment in interaction effects. Similarly Sharanabasappa et al. 2007 reported that the collar diameter was significantly increased in Agro forestry system with $100 \%$ Vermi compost indicating an organic fertilizer had a marginal effect on vegetative growth in patchouli.

The application of Vermi compost enhances the activity of beneficial microbes like $\mathrm{N}_{2}$ fixers and colonization by Mycorrhizal fungi and hence plays a significant role in $\mathrm{N}_{2}$ fixation and phosphate mobilization leading to better uptake by the plant. Thus the increased availability of nutrients and uptake by the plants would have resulted in maximum plant height, collar diameter and number of leaves in plots treated with vermi compost in the present experiment under multitier Agro forestry system.

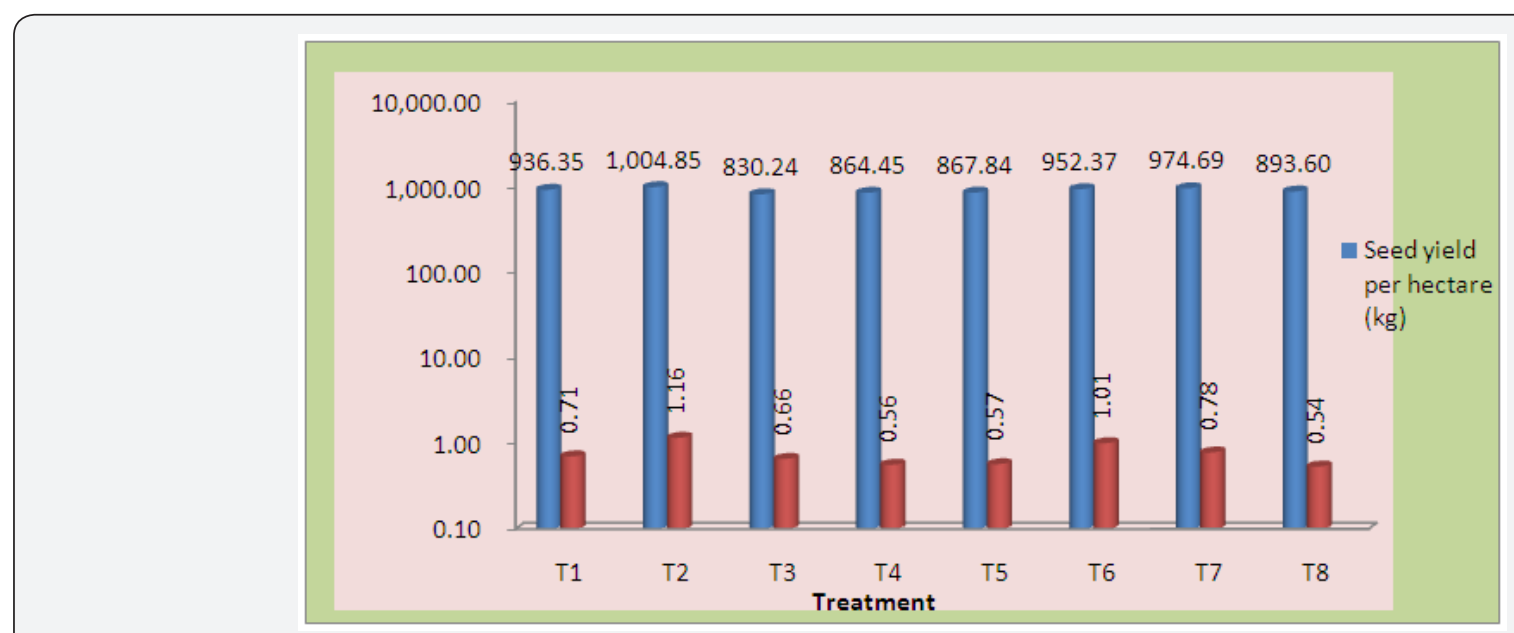

Figure 2: Effect of organic manure and inorganic fertilizer treatments on seed and oil yield of Muskdana (Abelmoschus moschatus) intercropped under Acacia mangium based multitier Agro forestry System.

\section{Yield Attributes}

Table 1 revealed that the number of capsules per plant, number of seed per capsules and seed test weight of Muskdana showed that $\mathrm{T}_{2}$ treatment $100 \%$ vermi compost produced maximum number of capsule, number of seeds and seed test weight (22.37 No, 110 . No. and 1.78 gram) respectively, followed by $\mathrm{T}_{1}, 21.50$ no. of capsules/plant; $\mathrm{T}_{6}, 108.67$ seed/capsule and T6, 1.69 gram seed test weight. However lowest no. of capsule per plot was found in $\mathrm{T}_{3}$, (15.74 no. of capsule/plant and 99.67 no. of seed/capsule) and lowest seed test weight $\mathrm{T}_{8}, 1.56$ gram/100 seeds. Similar findings have been reported by $[7,8]$ in Abelmoschus moschatus crop, [9] in Sweet flag and [10] in Sweet basil.

\section{Seed and Oil Production}

After harvest the seed yield was computed and presented in (Table 1) (Figure 2) Seed yield showed statistically significant $(\mathrm{P}<0.05)$ by organic manure and fertilizer treatments under Agro forestry system and as a sole crop in open condition without trees. Seed yield was recorded highest in treatment T2
(10.04 q/ha), followed by ( $9.74 \mathrm{q} / \mathrm{ha}$ ) in $\mathrm{T}_{7}$ respectively under shade condition. However, minimum seed yield was observed in Mahua cake $100 \%$ treatment ( $\left.8.30 \mathrm{q} \mathrm{ha}^{-1}\right)$ in Muskdana. Volatile oil - yield showed statistically significant $(\mathrm{P}<0.05)$ by organic manure and fertilizer treatments under Agro forestry system and open condition. The data appended in (Table 1) (Figure 2) revealed that maximum volatile oil yield was recorded in treatment $\mathrm{T}_{2}\left(1.16 \mathrm{~kg} \mathrm{ha}^{-1}\right)$ followed by $\left(1.01 \mathrm{~kg} \mathrm{ha}^{-1}\right)$ in $\mathrm{T}_{6}$ respectively under multitier Agro forestry system as compared with the other treatment and in sole crop with RDF. However, minimum volatile oil yield was observed in treatment T8 0.54 $\mathrm{kg} \mathrm{ha}^{-1}$ ) Muskdana as a sole crop. However $\mathrm{T}_{6}$ treatment the oil $\%$ was second highest after $\mathrm{T}_{2}$ might be because of nutrient availability and slow constant release of nutrient enhances the oil content may be one of the reasons. Similar findings were obtained by $[6,11]$ in Patchouli. Reported that higher oil recovery from 0 . sanctum under Silvi-medicinal may have resulted due to better soil nutrient status and positive effect of tree shade [12] also reported significant effects on essential oil recovery from O. sanctum grown under Peach, Grewia, and Morus based Agro forestry system [13-20]. 
The effect of intercropping on the growth of tree results showed that there was a minor difference in height increment in the tree after harvest of intercrops because of 10 month period did not showed much increment in height and diameter. Thus, in the present study it could be concluded that $100 \%$ vermi compost, $100 \%$ FYM and their combination are the best organic sources for Muskdana seed and oil production, when compared to other sources of organic and inorganic nutrients under multitier Agro forestry system as compare with the sole crop without tree and recommended to cultivate this crop under tree based Agro forestry system for higher income [20-23].

\section{Acknowledgement}

Authors are thankful to Department of Forestry, IGAU, Raipur (C.G.) who provides me the research insights illuminating guidance, continuous encouragement, scholarly suggestion, constrictive criticisms, sympathetic attitude and plausible appreciation during my research work.

\section{References}

1. Anuja S, Jayasri P (2011) Effect of organic nutrients on flowering and herbage yield of sweet basil (Ocimum basilicum L.). Adv Plant Sci 24(2): 601-603.

2. Attarde SB, Narkhede SD, Patil RP, Ingle ST (2012) Effect of organic and inorganic fertilizers on the growth and nutrient content of Abelmoschus esculentus (okra crop). International Journal of Current Research 4(10): 137- 140.

3. Brewbaker JL, Van den Beldt R, MacDicken K (1982) Nitrogen fixing tree resources: potentials and limitations. In: Graham PH and Harris SC (Ed) BNF Technology for Tropical Agriculture. CIAT, Cali, Colombia, pp. 413-425.

4. Brewbaker JL, Van den Beldt R, MacDicken K (1984) Fuel wood uses and properties of nitrogen fixing trees. Pesquisa Agropecuaria Brasileira 19: 193-204.

5. Clevenger JF (1928) Apparatus for determination of volatile oil. J Am Pharm Assoc 17: 346-348.

6. Hegde M, Palanisamy K, Seon J (2013) Acacia mangium Willd. - A Fast Growing Tree for Tropical Plantation. Journal of Forest Science 29(1): $1-14$.

7. Hegde NK, Siddappa R, Hanamashetti SI (2010) Response of curry leaf (Murraya koenigii spreng) 'suvasini' for foliar spray of Vermiwash and nutritional treatments. International Horticultural Congress on Science and Horticulture for People pp. 933-935.

8. Hemalatha P, Suresh J, Saraswathi T, Vadivel E (2008) Studies on the nutrient content herbage yield and alkaloid content of Kalmegh under integrated nutrient management system. Ad Pl Sci 21(2): 447-451.

9. Jha KK, Gupta C (1994) Intercropping of medicinal plants with Poplar and their phenology. Indian Forester 7(1): 117-118.
10. Kalyanasundaram B, Senthilkumar T, Kumar S, Swaminathan V (2008) Influence of integrated nutrient management on yield, nutrient content, quality and economics of cultivation of sweet flag (Acorus calamus L.). Adv Pl Sci 21(I): 277-280.

11. Kumar A, Suvera H, Thakur NS, Jha SK (2015) Herbage and essential oil yield of ocimum spp. Intercropped under pongamia pinnata based silvi medicinal. An International Quarterly Journal of Life Science 10(1): 81-85.

12. Kumar D, Mehera B, Kalra A, Bijalwan A (2014) Yield and oil quality of Patchouli [Pogostemon cablin (Blanco) Benth.] under Teak (Tectona grandis Linn.f.) based Agro forestry system in India. Research Journal of Forest and Environmental Protection 1(2): 81-88.

13. Law Ogbomo KE (2011) Comparison of growth, yield performance and profitability of tomato (Solanum lycopersicon) under different fertilizer types in humid forest ultisols. International Research Journal of Agricultural Science and Soil Science 1(8): 332-338.

14. Manjunath R, Farooqi AA, Vasundhara MV, Srinivasappa KN (2002) Effect of biofertilizers on growth, yield and essential oil content in Patchouli (Pogostemon cablin Pellet.). Indian Perfumer 46 (2): 97-104.

15. Maske SN, Munde GR, Maske NM (2011) Effect of manures and fertilizer on brinjal (solanum melongena l.) cv Krishna International Research Journal of Agricultural Science and Soil Science 1(8): 332-338.

16. Oroka, Frank Oke (2016) Morphological and yield attributes of okra (Abelmoschus esculentus l. Moench) as influenced by vermi compost + NPK nutrient sources. Advances in life science and technology 40: 46-50.

17. Patil SJ, Patil HY, Mutanal SM, Shahapurmath G (2012) Growth and productivity of Acacia mangium clones on shallow red soil. Karnataka J Agric Sci 25 (1): 94-95.

18. Prajapati RK, Kog V, Meshram S (2007) Standardization of optimum nitrogen requirement of Patchouli intercropped under Gmelina arborea based Agrisilviculture system in Chhattisgarh. Journal of Agricultural Issues 12(1): 97-100.

19. Purohit AN (1994) Eco physiology of fast and slow growing trees and some emerging trends. J Tree Sci 13(1): 1-12.

20. Rajeswari R, Shakila A (2015 a) Influence of season and spacing on the growth performance of ambrette (Abelmoschus moschatus Medic.) The Asian Journal of Horticulture 10(1): 71-75.

21. Rajeswari R, Shakila A (2015 b) Effect of integrated nutrient management practices on yield characters of ambrette (Abelmoschus moschatus medic.). Plant Archives 15(1): 537-540.

22. Rajeswari R, Shakila A (2015 c) Effect of season and spacing on flowering and yield performance of Ambrette (Abelmoschus moschatus Medic.). International Journal of Agricultural Sciences 11(2): 277-281.

23. Thakur NS, Verma KS, Rana RC (2009) Effect of tree-crop combinations and nitrogen levels on fresh herbage and oil yield of sacred basil (Ocimum sanctum) grown in agri horti-silvi pasture system in mid hill Himalayas. Indian Perfumer 53(2): 39-44. 
Your next submission with Juniper Publishers will reach you the below assets

- Quality Editorial service

- Swift Peer Review

- Reprints availability

- E-prints Service

- Manuscript Podcast for convenient understanding

- Global attainment for your research

- Manuscript accessibility in different formats

( Pdf, E-pub, Full Text, Audio)

- Unceasing customer service

Track the below URL for one-step submission https://juniperpublishers.com/online-submission.php 